\title{
Kecernaan Serat dan Fermentasi Kulit Buah dan Pelepah Nipah Menggunakan Mikro Organisme Lokal (MOL)
}

\author{
Suryadi, Ubaidillah, Farizaldi \\ Fakultas Peternakan Universitas Jambi \\ Correspondence email: suryadi.200759@gmail.com
}

\begin{abstract}
Abtract. This study aims: to determine the appropriate length of fermentation time for nipah fruit skin and nipah midrib so that the nutritional value and digestibility of cellulose and hemicellulose are increased. The study used a completely randomized design with 2 factor, namely: the type of material and the length of time of fermentation and was repeated 3 times. The first factor is the type of material: nipah fruit skin and palm fronds. Factor II, namely the lenght of fermentation time : 5 days, 10 days, 15 days and 20 hari hearts. Variables measured were crude fiber content, crude protein, cellulose digestibility and hemicellulose digestibility. The results showed that the digestibility of cellulose and hemicellulose digestibility of nipah fruit peels and palm fronds were significantly different $(P<0,05)$ but the crude fiber and crude protein $(M O L)$. In general, the digestibility of cellulose and hemicellulose inscreases with increasing fermentation time. The best digestibility occurred at 15 days of fermentation time for cellulose digestibility 64,69\% and hemicellulose digestibility 72,43\%. The interaction between nipah fruit skin and fermentation time of 20 days showed optimal results on hemicellulose digestibility.
\end{abstract}

Keywords: digestibility; fermentation; microorganisms; nipah fruit skin and Palm Fronds

\section{PENDAHULUAN}

Potensi limbah kulit buah dan pelepah nipah cukup besar untuk dapat dimanfaatkan sebagai sumber pakan hijauan alternatif bagi ternak ruminansia.

Menurut Baharuddin dan Taskirawati (2009), Limbah kulit buah dan pelepah nipah diperkirakan 48 ton/ha/th. Limbah nipah ini dibiarkan membusuk dan kadangkala digunakan sebagai kayu bakar oleh masyarakat.

Penggunaan limbah kulit buah dan pelepah nipah sebagai pakan ternak ruminansia secara umum dibatasi oleh kualitas nutrisi yang rendah akibat kandungan serat yang tinggi sehingga limbah tersebut belum bisa diberikan secara langsung pada ternak. Menurut Tamunaidu dan saka (2011), kulit buah nipah mengandung 36,5\% selulosa dan kadar lignin sebesar $27,3 \%$ sedangkan pelepah nipah mengandung serat kasar $50,5 \%$ dan selulosa $42,22 \%$ dan lignin $19,85 \%$ (Akpakpan, 2011). Untuk meningkatkan penggunaan kulit buah dan pelepah nipah perlu dilakukan melalui penerapan teknologi yaitu metode fermentasi.

Fardiaz (1992) menyatakan, Fermentasi berfungsi untuk memperbaiki nilai nutrisi bahan pakan, sebagai pengawet bahan dan mengurangi kehilangan zat anti nutrisi dalam suatu bahan makanan. Dalam proses fermentasi, mikroorganisme akan merombak struktur kompleks menjadi struktur yang lebih sederhana sehingga lebih efisien (Kompiang dkk, 1992). Mikrobiotik yang digunakan untuk meningkatkan kualitas limbah dari kulit buah dan pelepah nipah adalah mikro organisme lokal (MOL) yang berasal dari limbah sayur pasar.

MOL sayur dapat menurunkan kandungan serat kasar limbah kulit nenas sebesar 6,84\% (Adrizal et al., 2017) dan kandungan serat kasar limbah kulit pinang sebesar 23,85\% (Mahata dkk., 2018). Komponen serat berupa selulosa dan hemiselulosa yang terikat pada lignoselulosa dan lignohemiselulosa tersebut dapat dimanfaatkan sebagai sumber energi (Imsya dan Palupi, 2009).

Lama penyimpanan dilakukan untuk mengetahui sejauh mana pendegradasian kadar lignoselulosa dan lignohemiselulosa limbah kulit buah dan pelepah nipah.

Lama pemeraman dengan $\mathrm{EM}_{4}$ pada limbah kulit buah dan pelepah nipah dapat menurunkan kandungan selulosa dan lignin (Banta et al., 2011 ).

Berdasarkan uraian tersebut maka perlu dipelajari proses fermentasi kulit buah dan pelepah nipah dengan menggunakan MOL sayur ditinjau dari nilai nutrisi dan kecernaan serat secara in sacco.

\section{METODE}

Bahan yang digunakan dalam penelitian adalah kulit buah dan pelepah nipah, mikroorganisme lokal (MOL) sayur, sapi berfistula rumen, larutan NDS (Neutral Detergent Solution), larutan ADS (Acid Detergent Solution) dan perlengkapan fermentasi. Selama penelitian sapi fistula diberi ransum terdiri dari rumput lapangan dan konsentrat seperti: dedak, jagung giling dan mineral.

Alat yansg digunakan adalah timbangan pakan, oven pengering, ember plastik, alat tulis dan seperangkat alat kecernaan in sacco (kantong nilon, selang plastik, rubber stopper, tali penggantung). Kulit buah pelepah nipah berasal dari Kabupaten Tanjab Barat dan MOL diperoleh dari limbah sayur yang ada dipasar kota Jambi.

Peralatan yang digunakan adalah timbangan pakan, wadah fermentasi, oven, kertas saring, ember plastik, parang, alat tulis dan seperangkat alat kecernaan in Sacco (kantong nilon, selang plastik, rubber stopper). 
MOL sayur diperoleh dari limbah sayur yang ada dipasar kota Jambi.

\section{Pelaksanaan Fermentasi}

Penelitian ini dilakukan dalam dua tahap, tahap pertama yaitu fermentasi.

Kulit buah nipah dan pelepah nipah yang telah dibersihkan dipotong berukuran $2-3 \mathrm{~cm}$ lalu dikeringkan. Kulit buah dan pelepah nipah yang telah digiling halus ditimbang $\pm 200 \mathrm{~g}$, lalu ditempat dalam wadah plastik yang bertutup, kemudian ditambah $500 \mathrm{ml}$ MOL sayur, aduk sampai homongen. Kemudian diberi identitas pada masing-masing sampel tersebut pada kulit buah dan pelepah nipah. Selanjutnya difermentasi selama 5, 10, 15 dan 20 hari sesuai dengan perlakuan dalam kondisi an aerob. Setelah selesai fermentasi dilakukan analisis proksimat yaitu serat kasar dan protein kasar.

Tahap kedua dilakukan kecernaan secara in sacco dilakukan dengan menggunakan sapi jantan berfistula rumen menurut metode Orskov et al. (1992).

Kulit buah nipah dan pelepah nipah hasil fermentasi digiling dengan ukuran $2 \mathrm{~mm}$, kemudian masing-masing perlakuan ditimbang sebanyak \pm 5 gram (berdasarkan bahan kering) dimasukan kedalam kantong nilon. Sebelum dimasukan kedalam rumen sapi melalui fistula dengan lama inkubasi 72 jam. Setelah 72 jam kantong nilon dikeluarkan dari rumen, kemudian dicuci dengan air mengalir sampai airnya bersih dan dikeringkan dalam oven selama 24 jam dengan suhu $60^{\circ} \mathrm{C}$.ian Kemudian dilakukan analisis Neutral Detergent Fiber (NDF), Acid Detergent Fiber (ADF) dan selulosa menurut metode Goering dan Van Soest (1970).

Penelitian dilakukan dengan menggunakan Rancangan Acak Lengkap (RAL) dengan 2 faktor yaitu jenis bahan dan lama fermentasi dan diulang sebanyak 3 kali. Faktor I : Jenis bahan yaitu kulit buah nipah dan pelepah nipah, Faktor II. Lama waktu fermentasi terdiri dari 4 level yaitu 5, 10, 15 dan 20 hari.

Data dianalisis dengan analisis ragam (ANOVA) dan bila terdapat perbedaan maka dilanjutkan dengan uji jarak Duncan (Steel and Torrie, 1991).

Peubah yang diamati adalah nilai nutrisi, kecernaan selulosa dan hemiselulosa hasi fermentasi. Nilai kecernaan selulosa dan hemiselulosa ditetapkan menggunakan metode Tilley and Terry yang dimodifikasi oleh Sutardi (1980). Kandungan serat kasar dan protein kasar diperoleh melalui analisis proksimat metode Weendi (AOAC, 2000).

\section{HASIL DAN PEMBAHASAN Nilai nutrisi hasil fermentasi}

Pengaruh berbagai jenis bahan dan lama fermentasi pada kulit buah dan pelepah nipah menggunakan mikro organisme lokal (MOL) sayur. Rataan kandungan serat kasar dan protein kasar pada setiap perlakuan dapat dilihat pada Tabel 1 .

Tabel 1. Rataan kandungan serat kasar dan protein kasar kulit buah dan pelapah nipah hasil fermentasi menggunakan MOL

\begin{tabular}{ccccccc}
\hline Lama & \multicolumn{3}{c}{ Kandungan serat kasar $(\%)$} & \multicolumn{3}{c}{ Kandungan protein kasar $(\%)$} \\
\cline { 2 - 6 } Fermentasi & Kulit buah & Pelepah nipah & Rataan & Kulit buah & Pelepah nipah & Rataan \\
\hline 5 hari & 21,20 & 31,22 & 26,21 & 7,79 & 6,15 & 6,97 \\
10 hari & 21,35 & 30,94 & 26,15 & 7,97 & 7,05 & 7,51 \\
15 hari & 22,96 & 30,33 & 26,64 & 5,53 & 7,35 & 6,44 \\
20 hari & 24,10 & 31,39 & 27,74 & 6,86 & 7,08 & 6,97 \\
\hline
\end{tabular}

\section{Kandungan Serat Kasar}

Serat kasar (Crude fiber) adalah komponen serat yang tidak larut dalam larutan asam maupun basa lemah. Kandungan serat kasar meliputi selulosa, hemiselulosa, lignin, kutin dan pentosan-pentosan.

Dari hasil analisis ragam menunjukkan bahwa jenis bahan, lama fermentasi dan interaksi berpengaruh tidak nyata $(\mathrm{P}>0,05)$ terhadap kandungan serat kasar kulit buah maupun pelepah nipah.

Kandungan serat kasar yang tidak berbeda dari kulit buah nipah dan pelepah nipah akibat lama waktu fermentasi disebabkan oleh karena mikroorganisme lokal (MOL) sayur hanya mampu melonggarkan ikatan komplek lignin dengan selulosa yang terdapat pada dinding sel dan pertumbuhan mikroorganisme belum maksimal sehingga kandungan serat kasar relatif sama setiap perlakuan. Hasil ini didukung oleh pendapat Haryanto dkk. (1991) yang menyatakan bahwa peranan mikroba sesulolitik akan menentukan tingkat degradasi lignoselulosa, hasil degradasi tersebut digunakan sebagai energi bagi mikroba dalam proses fermentasi bahan berserat. MOL mengandung mikroorganisme antara lain : Rhizobium sp, Azospirillium sp, Azotobacter sp, Pseudomonas sp, Baccilus sp dan bakteri pelarut phosphat (Rahayu dan Tamtomo, 2017).

Penelitian ini menghasilkan kandungan serat kasar dari kulit buah dan pelepah nipah yang tidak berbeda. Artinya bahwa lama fermentasi tidak berpengaruh terhadap kandungan serat kasar. Hasil penelitian ini tidak sejalan dengan penelitian Mahata et al. (2018) yang menyatakan bahwa terjadinya penurunan kandungan serat kasar pada kulit buah pinang yang difermentasi dengan MOL sayur. Perbedaan kandungan serat kasar ini disebabkan oleh perbedaan bahan yang digunakan, metodenya dan waktu fermentasi. 


\section{Kandungan Protein Kasar}

Protein kasar adalah semua zat yang mengandung nitrogen. Hasil analisis ragam menunjukkan bahwa jenis bahan, lama fermentasi dan interaksi tidak menunjukkan perbedaan yang nyata $(\mathrm{P}>0,05)$ terhadap kandungan protein kasar kulit buah dan pelepah nipah yang dihasilkan.

Kandungan protein kasar yang tidak berbeda pada penelitian ini diduga karena tidak ada penambahan bahan lain sebagai sumber karbon dan nitrogen yang berguna dalam perkembangan bakteri sehingga akan mempengaruhi layu fermentasinya. Selain itu juga rendahnya sumbangan protein yang berasal dari mikroorganisme sayur untuk penyediaan protein kasar kulit buah nipah maupun pelepah nipah. Sesuai dengan pendapat Murbandono (2002) yang menyatakan bahwa jasad renik yang menguraikan bahan-bahan organik menjadi anorganik memerlukan senyawa-senyawa $\mathrm{N}$ untuk perkembangan sehingga semakin banyak kandungan senyawa $\mathrm{N}$ makin cepat pula proses fermentasi.

Dari tabel 1 diketahui bahwa kandungan protein kasar tertinggi pada lama fermentasi 10 hari yaitu sebesar $7,51 \%$ dan terendah pada lama fermentasi 15 hari yaitu $6,44 \%$. Hasil penelitian ini lebih rendah dibandingkan hasil penelitian Mahata et al. (2018) dimana kandungan protein kasar kulit buah pinang fermentasi sebesar 10,39\%.

Perbedaan kandungan protein kasar penelitian ini karena perbedaan bahan yang digunakan dan lama fermentasi.

\section{Kecernaan serat hasil fermentasi}

Hasil pengukuran nilai kecernaan serat secara in sacco dan hasil analisis statistik tiap perlakuan dapat dilihat pada Tabel 2.

Tabel 2. Rataan kecernaan selulosa dan hemiselulosa kulit buah dan pelapah nipah hasil fermentasi

\begin{tabular}{ccccccc}
\hline Lama Fermentasi & \multicolumn{3}{c}{ Kecernaan selulosa (\%) } & \multicolumn{3}{c}{ Kecernaan hemiselulosa (\%) } \\
\cline { 2 - 7 } & Kulit buah & Pelepah nipah & Rataan & Kulit buah & Pelepah nipah & Rataan \\
\hline 5 hari & 37,47 & 35,20 & $36,33 \mathrm{~b}$ & $66,22 \mathrm{~b}$ & $45,49 \mathrm{a}$ & $55,85 \mathrm{~b}$ \\
10 hari & 57,19 & 58,74 & $57,96 \mathrm{a}$ & $67,87 \mathrm{~b}$ & $72,13 \mathrm{~b}$ & $69,99 \mathrm{a}$ \\
15 hari & 67,50 & 61,89 & $64,69 \mathrm{a}$ & $68,36 \mathrm{~b}$ & $76,52 \mathrm{~b}$ & $72,43 \mathrm{a}$ \\
20 hari & 68,09 & 51,98 & $60,04 \mathrm{a}$ & $78,27 \mathrm{~b}$ & $41,91 \mathrm{a}$ & $60,09 \mathrm{~b}$ \\
\hline
\end{tabular}

Keterangan: Angka dengan huruf yang sama menunjukkan tidak berbeda nyata $(\mathrm{P}>0,05)$ pada uji jarak Duncan

\section{Kecernaan Selulosa}

Selulosa merupakan polimer dari molekulmolekul selobiosa yang membentuk ikatan 1,4 glukosida yang lebih tahan terhadap reagent kimia. Hasil akhir pencernaan selulosa di dalam rumen adalah asam lemak terbang (VFA) yang merupakan sumber energi utama bagi ternak ruminansia (Tillman et al., 1991).

Pada tabel 2 terlihat kecernaan selulosa meningkat dengan bertambahnya lama waktu fermentasi. Berdasarkan hasil analisis ragam pada inkubasi 72 jam menunjukkan bahwa kecernaan selulosa sangat nyata $(\mathrm{P}<0,05)$ dipengaruhi oleh lama waktu fermentasi. Dari hasil uji jarak duncan menunjukkan bahwa kecernaan selulosa dengan lama fermentasi 15 hari berbeda nyata $(\mathrm{P}<0,05)$ dengan lama fermentasi 5 hari, tetapi tidak berbeda nyata dengan lama fermentasi 10 hari dan 20 hari.

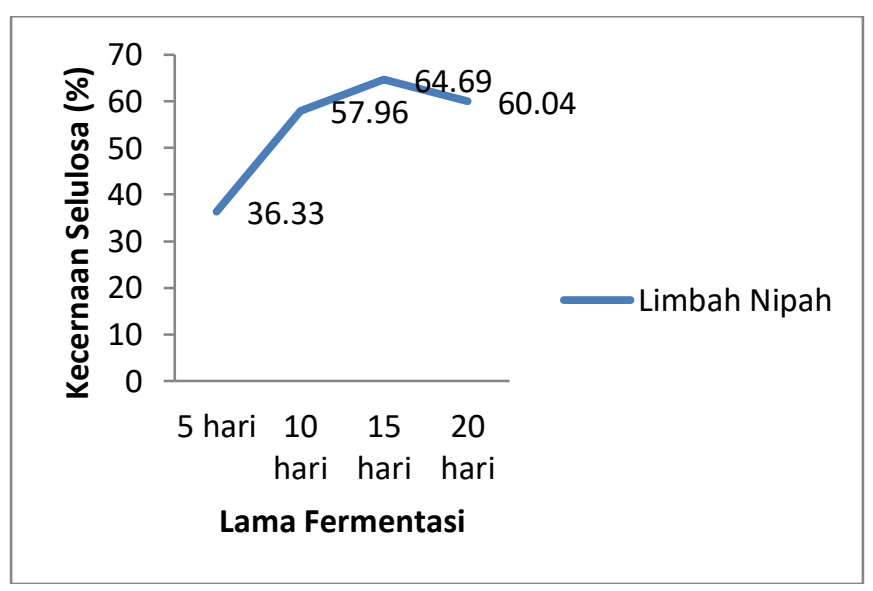

Gambar 1. Grafik Hubungan Kecernaan Selulosa Dengan Lama Fermentasi

Pada gambar 1 dapat dilihat kecernaan selulosa mengalami peningkatan sampai taraf fermentasi 15 hari, kemudian menurun pada lama fermentasi 20 hari.

Peningkatan kecernaan selulosa ini disebabkan karena adanya aktivitas bakteri selulolitik dalam rumen yang mampu mendekomposisi lignoselulosa sehingga kandungan lignin menjadi rendah. Giroux et al. (1988) menambahkan semakin lama pemeraman maka aktivitas bakteri melarutkan lignin menjadi acid precipitable polymeric lignin (APPL) semakin tinggi dikarenakan didukung oleh ketersediaan substrat dari lignoselulosa yang mencupi. Sullivan (1965) menyatakan bahwa 
kandungan lignin berkorelasi negatif dengan degradasi selulosa.

Lama fermentasi 20 hari, 15 hari dan 10 hari tidak menunjukkan perbedaan yang nyata $(\mathrm{P}>0,05)$ terhadap kecernaan selulosa. Hal ini diduga karena kandungan lignin yang dihasilkan dalam rumen relatif sama setiap perlakuan. Smith et al. (1984) menyatakan bahwa kandungan lignin yang relatif sama menyebabkan degradasi selulosa yang relatif sama pula.

Kecernaan selulosa tertinggi diperoleh pada lama fermentasi 15 hari yaitu 64,69\% (Gambar 1). Nilai kecernaan selulosa penelitian ini lebih tinggi dibandingkan dengan hasil penelitian Ghunu (1998) dimana kecernaan selulosa ampas tahu yaitu sebesar 44,39\%. Perbedaan nilai kecernaan tersebut disebabkan oleh karena perbedaan komposisi bahan dan metode yang digunakan serta lama inkubasi. McDonald et al. (2002) menyatakan bahwa faktor-faktor yang mempengaruhi kecernaan antara lain: komposisi bahan pakan, perbandingan komposisi bahan, perlakuan bahan, suplementasi enzim dalam pakan, ternak dan taraf pemberian pakan.

Analisis ragam memperlihatkan bahwa interaksi antara jenis bahan dengan lama fermentasi tidak nyata mempengaruhi kecernaan selulosa kulit buah dan pelepah nipah, namun ada kecendrungan terjadinya peningkatan kecernaan selulosa seiring meningkatnya lama waktu fermentasi.

\section{Kecernaan Hemiselulosa}

Hemiselulosa adalah suatu nama untuk menunjukkan suatu golongan substansi yang termasuk di dalamnya adalah araban, heksosa tertentu dan poliuronat yang lebih tidak tahan kena agent kimia dibandingkan selulosa (Tillman et al., 1991).

Semakin meningkat lama waktu fermentasi maka semakin tinggi kecernaan hemiselulosa. Dari hasil analisis statistika pada inkubasi 72 jam menunjukkan bahwa lama fermentasi berpengaruh nyata $(\mathrm{P}<0,05)$ terhadap kecernaan hemiselulosa. Berdasarkan uji duncan diperoleh bahwa tingkat kecernaan hemiselulosa dengan lama fermentasi 15 hari berbeda nyata $(\mathrm{P}<0,05)$ dengan lama fermentasi 5 hari, tetapi tidak berbeda dengan lama fermentasi 10 hari dan 20 hari. Pola kecernaan hemiselulosa ini sama dengan kecernaan selulosa.

Kecernaan hemiselulosa tertinggi pada lama fermentasi 15 hari dibandingkan dengan perlakuan lain diduga karena tingginya kelarutan hemiselulosa yang dapat dicerna oleh mikroorganisme dalam rumen. Pernyataan ini diperkuat oleh pendapat Tillman et al. (1991) bahwa kelarutan yang tinggi didalam rumen dikarenakan komponen penyusun dari hemiselulosa adalah polimer dari karbohidrat yang mengandung gula heksosa, pentosa, araban, xilan dan poliuronat tidak tahan kena agent kimia dibandingkan selulosa.
Kecernaan hemiselulosa dengan lama fermentasi 20 hari, 15 hari dan 10 hari tidak berbeda diduga karena tingkat kelarutan hemiselulosa yang dapat dicerna oleh kultur mikroorganisme rumen relatif sama setiap perlakuan. Hasil penelitian ini didukung oleh pendapat Church dan Pond (1989), kelarutan hemiselulosa yang tinggi dalam rumen akan menghasilkan kecernaan yang tinggi pula, sebaliknya kelarutan yang sama akan menghasilkan kecernaan relatif sama pula.

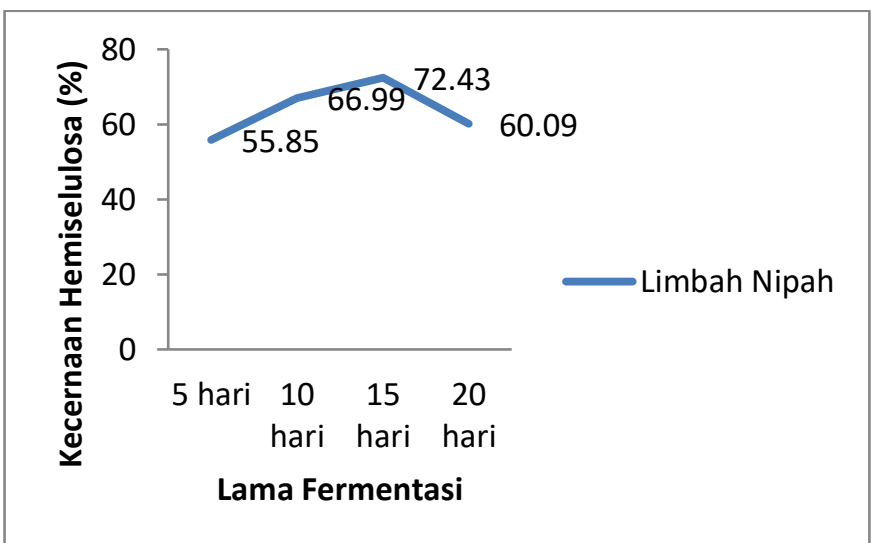

Gambar 2. Grafik Hubungan Antara Kecernaan Hemiselulosa dengan Lama fermentasi

Gambar 2 terlihat bahwa kecernaan hemiselulosa mengalami peningkatan sampai pada lama fermentasi 15 hari, kemudian menurun pada lama fermentasi 20 hari. Lama fermentasi 15 hari menghasilkan kecernaan hemiselulosa tertinggi yaitu $72,43 \%$, sedangkan kecernaan hemiselulosa paling rendah terjadi pada lama fermentasi 5 hari sebesar 55,85\%. Hasil penelitian ini lebih tinggi dibandingkan dengan hasil penelitian Ghunu (1998), dimana kecernaan hemiselulosa ampas tebu yaitu sebesar 52,99\%, dan hasil penelitian Suryadi dan Syafria (2018), dimana kecernaan hemiselulosa pelepah nipah sebesar $25,08 \%$. Perbedaan nilai kecernaan ini disebabkan oleh perbedaan komposisi bahan, metode yang digunakan dan lama waktu inkubasi.

Berdasarkan analisis ragam menunjukkan bahwa interaksi antara jenis bahan dengan lama fermentasi sangat nyata mempengaruhi kecernaan hemiselulosa kulit buah maupun pelepah nipah. Dimana semakin lama fermentasi pada umum kecernaan hemeselulosa semakin meningkat. Kombinasi kulit buah dengan lama fermentasi 20 hari merupakan perlakuan yang optimum pada kecernaan hemiselulosa, tetapi pada pelepah nipah tingkat optimum terjadi pada fermentasi 15 hari.

\section{SIMPULAN}

Jenis bahan dan fermentasi sampai 20 hari tidak berpengaruh nyata $(\mathrm{P}>0,05)$ terhadap kandungan serat kasar dan protein kasar tetapi berpengaruh nyata $(\mathrm{P}<0,05)$ terhadap kecernaan selulosa dan kecernaan hemiselulosa pada kulit buah maupun pelepah nipah. Kecernaan selulosa dan kecernaan hemiselulosa terbaik 
terjadi pada fermentasi 15 hari masing-masing sebesar $64,69 \%$ dan $72,43 \%$. Terdapat interaksi antara jenis bahan dan lama fermentasi pada kecernaan hemiselulosa, kombinasi kulit buah dengan lama fermentasi 20 hari menunjukkan hasil yang optimal pada kecernaan hemiselulosa.

\section{DAFTAR PUSTAKA}

Adrizal, M.E., Mahata, Y., Heryandi and R. Amizar. 2017. Evaluation of pineapple (Ananascomosus (L) Merr) waste fermented using different local mikroorganisme solutions as poultry feed. Pakistan Journal of Nutrition. 16: 84-89.

AOAC, 2000. Offical Methods of Analysis. 12th Edition. Benjamin Franklin, Washington, D.C.

Akpakpan, A.E., U.D Akpabio, B.O., Ugunsile and U.M. Eduok. 2011. Influence of cooking variables on the soda and soda-ethanol pulping of nypa fructicans petiole. Australian Journal of basic and Applied Science 5:(12) : 1202-1208.

Baharuddin dan I. Taskirawati. 2009. Buku Ajar. Hasil Hutan Bukan Kayu. Fakultas Kehutanan. Universitas Hasanuddin.Makasar.

Banta, D., Susingih, W., Febrianto, A.M. 2011. Pengaruh lama pemeraman terhadap kadar lignin dan selulosa pulp (Kulit buah dan Pelepah nipah) Menggunakan Biodegradator $\mathrm{EM}_{4}$. J. Industri. Vol. 2. No. 1. Hal. 75-83

Church, D.C and W.G. Pond. 1989. Basic Animal Nutrition and Feeding. John Wiley and Sons. New York.

Fardiaz, S. 1992. Mikrobiologi Pangan I. Gramedia. Jakarta.

Ghunu, S. 1998. Efek dosis inokulum dan lama bioconversi ampas tebu sebagai bahan pakan oleh jamur tiram putih (Pleurotus ostreatus) terhadap kandungan komponen serat, protein kasar dan energi dapat dicerna pada domba. Thesis. Program Pascasarjana, Universitas Padjadjaran, Bandung.

Giroux, H., Vidal, P., Bouchard, J., Lamy, F. 1988. Degradasi of Kraft Indulin lignin by Streptomyces viridosporus T7A and Streptomyces badius. Application environment Microbiology. 54: 30643070.

Goering, H.K and Van Soest. P.J. 1970. Forage fiber analysis. Agricultural Handbook, USDA. No. 379. Washington, USA.

Haryanto, B., K. Diwyanto., Isbandi dan Suharto. 1991. Effect of Probiotik supplement on the growth and carcas yield of sheep. Paper submitted to VII AAAP Animal Science Conggress, Denpasar, Bali.

Imsya, A and Palupi, R. 2009. The change of lignin neutral detergent fiber and acid detergent fiber of palm frond with biodegumming process as fiber source feedstuff for ruminant. JITV. 14(4): 284287.
Kompiang, I.P., Sinurat., S. Kompiang., T. Purwadaria dan J. Darma. 1992. Nutritional value of protein enriched-cassapro. Ilmu dan Peternakan 7(8): 2225.

Mahata, M.E., Y. Rizal Ardi. 2018. Pengolahan dan pemanfaatan limbah kulit pinang (Areca catechu L.) sebagai pakan aditif ternak unggas. Laporan Penelitian. Hibah Kompetensi Dikti. Lembaga Penelitian dan Pengabdian Masyarakat Universitas Andalas.

Mc Donald, P., R. A. Edwards, J. F. D. Greenhalgh and C. A. Morgan. 2002. Animal Nutrition. 5 th Edition. Longman Scientific and Technical. New York.

Murbandono, H. S. L. 2002. Membuat Kompos. Penerbit Penebar Swadaya. Jakarta.

Orskov, E.R. 1992. Protein Nutrition in Ruminats. United States. Academic Press Ltd. London

P. Tamunaidu and S. Saka. 2011. Chemical Characterization of Variou Parts of Nipa Palm (Nypa fructicans). Industrial Crops dan Products. 34:1423-1428.

Rahayu, S dan Tamtomo. 2017. Efektifitas mikroorganisme lokal (mol) dalam meningkatkan kualitas kompos, produksi dan efisiensi pemupukan N, P,K pada tanaman ubi jalar (ipomoea batatas L.) Jurnal AGROSAINS. 13 (2).

Smith, L.W., H.K. Goering., D.R. Woldo and C.H. Gordon. 1984. In Vitro digestion rate of forage cell wall component. Anim. Sci. Research Division, USDA, Betsville, Maryland

Steel R.G.D. dan J.H. Torrie. 1991. Prinsip dan Prosedur Statistika. Bambang S, penerjemah. PT. Gramedia Pusat Utama. Jakarta.

Sullivan, J.T. 1965. Studies of the hemicellulose of forage plants. Chemist, Crops Research Division Agricultural Research Service. USDA. University Park. Pa.16802

Suryadi, H. dan H. Syafria. 2018. Biokonversi pelepah daun nipah menggunakan jamur tiram putih ditinjau dari komposisi kimia dan kecernaan serat.

Sutardi, T. 1980. Peningkatan Mutu Hasil Limbah Lignosellulosa sebagai Makanan Ternak. Institut Pertanian Bogor, Bogor.

Tillman, A.P., H. Hartadi., S. Reksohadiprodjo., P. Suharto dan S. Lebdosoekojo.1991. Ilmu Makanan Ternak Dasar. Gadjah Mada University Press. Yogyakarta. 